\title{
Microbial Efficacy of Beclomethasone Dental Paste in the Treatment of Periodontitis
}

\author{
Yashwanath Rao $\mathbf{M}^{1}$, Kavyashree PS ${ }^{2}$, Purushotham Rao $\mathbf{K}^{3 *}$, Satish $\mathbf{K}^{3}$ and Ajay Kartik ${ }^{4}$ \\ ${ }^{1}$ Department of Microbiology, MR Medical College, India \\ ${ }^{2}$ Department of Maxillo Facial Surgery, HKE Dental College and Hospital, India \\ ${ }^{3} H K E$ 's College of Pharmacy, India
}

${ }^{4}$ Panineeya Dental College and Hospital, India

Submission: August 20, 2017; Published: October 20, 2017

*Corresponding author: Purushotham Rao K, HKE's College of Pharmacy, Gulbarga (Karnataka), APTI Membership (KA/LM/132), India, Tel: 08472-226675; Email: kprao369@rediffmail.com

\begin{abstract}
In the present work, it was planned to prepare therapeutic medicated dental pastes for treatment of periodontitis and oral thrush, which provides effective treatment. Stress was given on local action of the drug and to treat initial stages of periodontitis and oral thrush. Beclomethasonedipropionate was chosen model drug which was a corticosteroid which has a wide range of anti-inflammatory activity. The prepared dental pastes were subjected for various physicochemical parameters like PH, Spread ability, tube extrudability, uniformity of drug content and IR studies. For this study periodontal infective pus sample of a patient collected from a patient under the supervision of dental professor of a local dental college. In-vitro drug release studies were carried out in PH 6.4 phosphate buffer. Stability studies of selected formulations were also done at ambient temperature $\left(30^{\circ} \mathrm{C}\right)$ for the period of six months as per ICH guidelines. The formulations were subjected for primary skin irritation test in healthy human volunteers for 72 hours. In vitro diffusion study showed good results in formulation F2, which showed more retentive time in oral cavity. During physicochemical studies significant results were obtained and found to be within the limits of official standards. The present work is being focused on designing of medicated tooth pastes to protect the gums, teeth and oral cavity from periodontal infections and oral thrush resulting from improper fixation of artificial dentures. The present study revealed that the prepared Beclomethasonedipropionate dental paste formulations will be useful in the treatment of oral thrush and periodontal diseases of all age groups of patients.
\end{abstract}

Keywords: Periodontitis and oral thrush; Beclomethasonedipropionate dental paste

\section{Introduction}

Oral diseases continue to be a major health problem worldwide. Dental caries and periodontal diseases are among the most important global oral health problems, although conditions such as oral and pharyngeal cancers and oral tissue lesions are also significant health concerns [1]. Despite general advances in the overall health status of the people living in industrialized countries, including oral and dental health, the prevalence of dental caries in school aged children is up to $90 \%$ and the majority of adults are also affected [2]. Oral health is integral to general well-being and relates to the quality of life that extends beyond the functions of the craniofacial complex. There is considerable evidence linking poor oral health to chronic conditions, for example, there is a strong association between severe periodontal diseases and diabetes [3].
There is also evidence linking poor oral health and systemic diseases, such as cardiovascular diseases, rheumatoid arthritis and osteoporosis [4], while periodontal diseases may also contribute to the risk of pregnancy complications, such as preterm low-birth weight [5]. Tooth loss, caused by poor periodontal health (which affects up to $20 \%$ of the adult population worldwide) can lead to significant morbidity and premature death. The economic impact of oral diseases is an important consideration with up to $10 \%$ of public health expenditure in developed countries related to curative dental care.

\section{Material and Methods}

Beclomethasonedipropionate was a gift sample from Alkem pharmaceuticals, Mumbai, Methyl cellulose, Methyl salicylate 
and Acacia (SD Fine Chemicals, Mumbai), Precipitated chalk, Glycerin and Alcohol (Qualigens Fine Chemicals, Mumbai), Sodium lauryl sulfate (Himedia Laboratories Ltd., Mumbai), Methyl parahydroxy benzoate (Loba Chemicals, Mumbai), Empty aluminum collapsible tubes (Digvijay containers and closures, Mumbai), Cellophane paper (Local market).

\section{Preparation of formulation}

Medicated dental paste was prepared by conventional triturating method. The formulations were prepared containing mucoadhesive polymer. The formulations were transferred and stored in collapsible tubes for further studies [6].

\section{Characterization of prepared beclomethasone dipropionate medicated pastes spread ability}

About $1 \mathrm{~g}$ of tooth paste was weighed at the centre of glass plate $(10 \mathrm{x} 10 \mathrm{~cm})$ and another glass plate is placed over it carefully. At the centre of the plate a $2 \mathrm{~kg}$ weight is placed. After $30 \mathrm{~min}$ the diameter of the paste was measured in $\mathrm{cm}$. The experiment was repeated thrice and average diameter is determined.

\section{Determination of $\mathbf{p H}$}

A weighed quantity of tooth paste $(10 \mathrm{~g})$ was taken in a $150 \mathrm{ml}$ beaker and $10 \mathrm{ml}$ of freshly boiled and cold water (at 27 ${ }^{\circ} \mathrm{C}$ ) is added, stirred well to make thorough suspension and the $\mathrm{pH}$ of the suspension is determined within $5 \mathrm{~min}$ using $\mathrm{pH}$ meter.

\section{Tube extrudability}

The method adopted for evaluating paste formulation for extrudability was based upon the quantity in percentage paste extruded from tube on application of finger pressure. More quantity extruded better was extrudability. The formulation under the study was filled in a clean, aluminum collapsible tube with a nasal tip of $5 \mathrm{~mm}$ opening and applied the pressure on the tube by the help of finger. Tube extrudability was then determined by measuring the amount of paste extruded through the tip when a pressure was applied on the tube.

\section{Determination of drug content uniformity}

$5 \mathrm{gm}$ medicated dental pastes (prepared formulation) was taken and dissolve in $50 \mathrm{ml}$ volt flask with small quantity of ethanol and volume is make up to $50 \mathrm{ml}$ with ethanol after that solution is filtered with what man filter paper which gives $1000 \mathrm{mcg} / \mathrm{ml}$ concentration. From this solution $1 \mathrm{ml}$ solution was transferred in $10 \mathrm{ml}$ volt flask and volume was made to $10 \mathrm{ml}$ with ethanol which gives $100 \mathrm{mcg} / \mathrm{ml}$ concentration. From this different concentration of solution was taken in $10 \mathrm{ml}$ volt flask and volume was made to $10 \mathrm{ml}$ with methanol and absorbance was measure by UV spectrophotometer at 238nm against blank. All the formulations were found within the specified limit of drug content.

\section{IR spectral analysis}

Infrared spectroscopy is one of the most powerful analytical techniques which offer the possible chemical identification.
In the present work, IR spectra of Beclomethasone and hydrocolloids were obtained by $\mathrm{KBr}$ pellet method.

\section{In-vitro drug diffusion studies}

A glass cylinder with both ends open, $10 \mathrm{~cm}$ height, $3.7 \mathrm{~cm}$ outer diameter and $3.1 \mathrm{~cm}$ inner diameter was used as permeation cell. A cellophane membrane soaked in distilled water $(24 \mathrm{hrs}$ before use) was fixed to the one end of the cylinder with the side of an adhesive to result in permeation cell. One gram of semisolid formulation was taken in the cell (donor compartment) and the cell was immersed in beaker containing $100 \mathrm{ml}$ of drug free $\mathrm{PH}$ 6.4 phosphate buffer as receptor compartment. The cell was immersed to a depth of $1 \mathrm{~cm}$ below the surface of receptor fluid. The medium in the receptor compartment was agitated using a magnetic stirrer and temperature of $37 \pm 1{ }^{\circ} \mathrm{C}$ was maintained. Samples $(5 \mathrm{ml})$ of the receptor compartment were taken at various intervals over a period of 90 minutes with replacement of equal amount of free receptor fluid. The samples were estimated by measuring the absorbance at $238 \mathrm{~nm}$ in $1800 \mathrm{UV}$ Shimadzu spectrophotometer.

\section{Evaluation for antimicrobial activity of formulations}

Antimicrobial activity of the formulations was evaluated according to the standard agar cup plate method in brain heart infusion agar media. In present media work, antibacterial activity of Beclomethasone dipropionate was tested for against causative microorganism of periodontitis in brain heart infusion agar plates by taking pus sample of oral cavity of diseased patient suffering from periodontitis under the supervision of a dentist. Inoculated in peptone broth and streaked in brain-heart infusion agar using cup and plate method and incubated at 37 ${ }^{\circ} \mathrm{C}$. The diameter of the zone of inhibition was measured and compared with marketed formulation (MF) as well as pure drug [7].

\section{Stability studies}

Table 1: Formulae used to prepare dental pastes.

\begin{tabular}{|c|c|c|c|}
\hline $\begin{array}{c}\text { Sl. } \\
\text { No. }\end{array}$ & Ingredient & $\begin{array}{c}\text { Without } \\
\text { Hydrocolloid } \\
\text { (F1) }\end{array}$ & $\begin{array}{c}\text { With } \\
\text { Hydrocolloid } \\
\text { (F2) }\end{array}$ \\
\hline 1. & Beclomethasonedipropionate & $25 \mathrm{mg}$ & $25 \mathrm{mg}$ \\
\hline 2. & Precipitated chalk & $56 \mathrm{gm}$ & $52 \mathrm{gm}$ \\
\hline 3. & Acacia & $1.2 \mathrm{~m}$ & $1.2 \mathrm{gm}$ \\
\hline 4. & Glycerin & $20 \mathrm{ml}$ & $20 \mathrm{ml}$ \\
\hline 5. & Methylcellulose & - & $4 \mathrm{gm}$ \\
\hline 6. & Sodium lauryl sulfate & $0.8 \mathrm{gm}$ & $0.8 \mathrm{gm}$ \\
\hline 7. & Methyl paraben & $0.216 \mathrm{gm}$ & $0.216 \mathrm{gm}$ \\
\hline 8. & Alcohol & $5 \mathrm{ml}$ & $5 \mathrm{ml}$ \\
\hline 9. & Methyl salicylate & $0.76 \mathrm{ml}$ & $0.76 \mathrm{ml}$ \\
\hline 10. & Distilled water & Q.S. to $100 \mathrm{gm}$ & Q.S. to $100 \mathrm{gm}$ \\
\hline
\end{tabular}

The prepared $0.025 \%$ Beclomethasonedipropionate dental paste formulations were filled in the collapsible tubes and stored at room temperature $\left(27 \pm 2^{\circ} \mathrm{C}\right)$ for the span of six months. Known amount of cream formulation were taken out at different time 
intervals (one month interval) and analyzed for drug content, physical appearance, $\mathrm{PH}$ and rheological properties (Table 1).

\section{Result and Discussion}

Results showed that all the formulations were shown good spreadbility and extrudability and all formulations were within $\mathrm{pH}$ range (Table 2). Drug content estimation, drug present in the formulations F1 and F2 were found to be $98.63 \%$ and $98.08 \%$ respectively. Results showed that the drug content was uniform in all the formulations. In-vitro drug release from medicated pastes prepared revealed that, in F1 and F2 at the end of 90 min, percent cumulative drug release was $81.43 \%$ and $63.41 \%$ respectively. To know precisely, the basic in-vitro drug release data was plotted (Figure 1). During microbiological investigation against the organism collected from the pus sample of dental patient, all formulation showed equal zone of inhibition when compared with the pure drug and marketed formulations (Table $2 \& 3$ ). In stability studies, all formulations are not segregate, ferment or physically deteriorated during normal condition of storage and use (Table 3 ). When stored at $27 \pm 2{ }^{\circ} \mathrm{C}$ for period of 6 month all the formulation did not undergo phase separation or gassing formulation or otherwise deterioration aesthetically [8-16]. The present study revealed that the prepared Beclomethasone dipropionate mucoadhesive dental paste formulations with more retentive time in oral cavity will be useful for more effective drug action (Figure $2 \& 3$ ).

Table 2: Characterization of prepared formulations.

\begin{tabular}{|c|c|c|c|c|c|}
\hline Formulation Code & Appearance & Spread Ability (Cm) & Tube Extrudability (\%) & PH & Drug Content (\%) \\
\hline F1 & White & 7.1 & 98.15 & 7.2 & 98.63 \\
\hline F2 & White & 7.4 & 96.56 & 6.4 & 98.08 \\
\hline
\end{tabular}

*Each reading is a mean of three replicates.

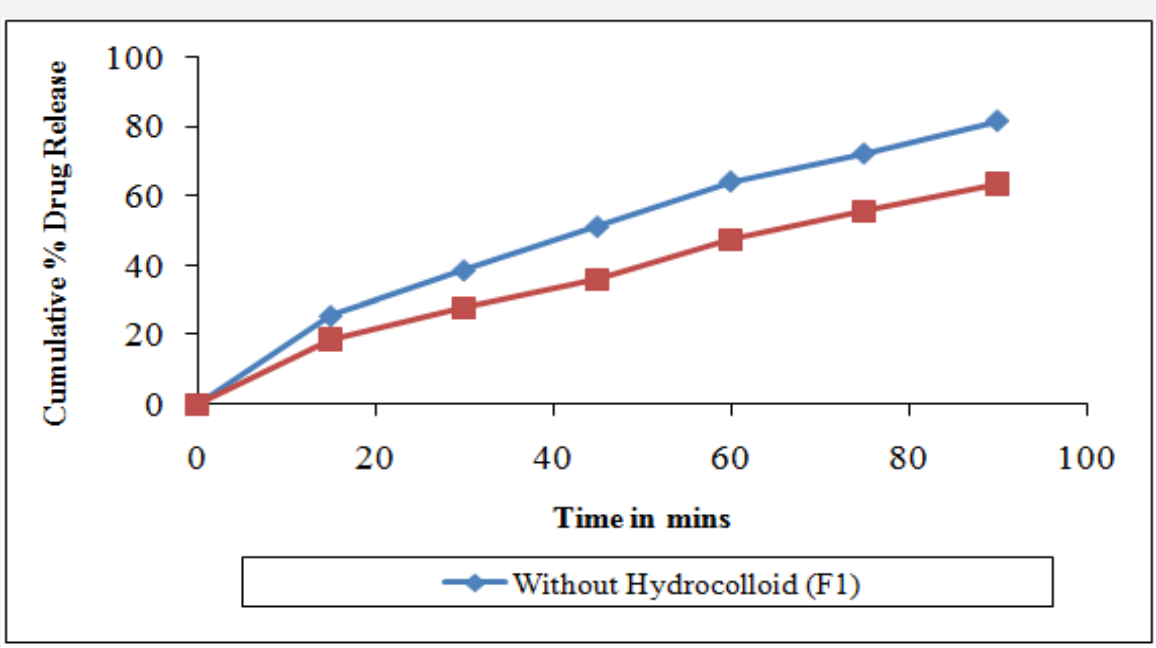

Figure 1: Comparative studies of Beclomethasonedipropionate dental pastes without hydrocolloid (F1) and with hydrocolloid $\left(F_{2}\right)$.
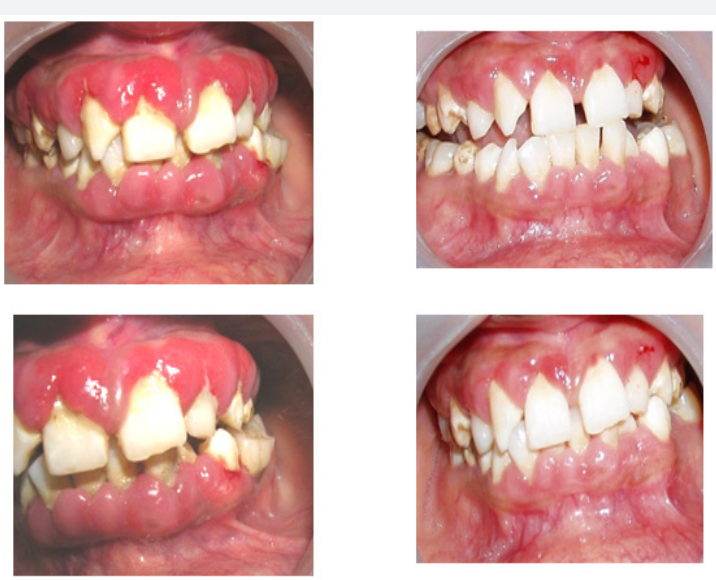

Figure 2: Photographs showing the effects of treatment during the clinical study.

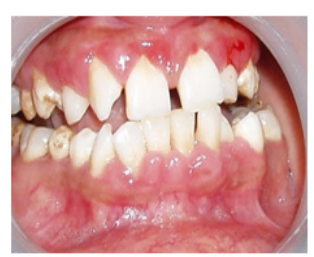
the Treatment of Periodontitis. Adv Biotech \& Micro. 2017; 6(5): 555698. DOI: 10.19080/AIBM.2017.06.555698.
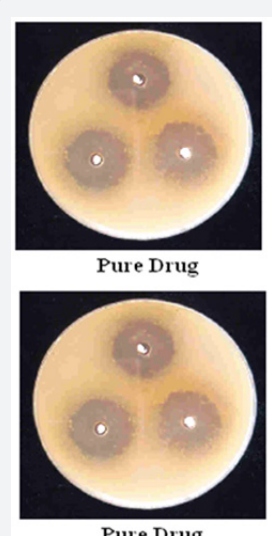

Pure Drug $\quad F_{2}$ Formulation formulations with pure drug and marketed formulation.
Figure 3: Comparative zone inhibition studies of drug in the 
Table 3: Comparative In vitro drug release studies of F1 and F2 Dental Formulations.

\begin{tabular}{|c|c|c|}
\hline \multirow{2}{*}{$\begin{array}{l}\text { Time in } \\
\text { Min }\end{array}$} & \multicolumn{2}{|c|}{ Cumulative \% Drug Release } \\
\hline & Without Hydrocolloid (F1) & With Hydrocolloid (F2) \\
\hline 0 & 0 & 0 \\
\hline 15 & $25.58 \pm 0.63$ & $18.85 \pm 0.85$ \\
\hline 30 & $38.75 \pm 0.84$ & $27.76 \pm 0.39$ \\
\hline 45 & $51.38 \pm 0.42$ & $36.12 \pm 0.51$ \\
\hline 60 & $64.05 \pm 0.62$ & $47.66 \pm 0.15$ \\
\hline 75 & $72.03 \pm 0.50$ & $55.83 \pm 0.27$ \\
\hline 90 & $81.43 \pm 0.33$ & $63.41 \pm 0.26$ \\
\hline \multirow{2}{*}{$\begin{array}{l}\text { Time in } \\
\text { Min }\end{array}$} & \multicolumn{2}{|c|}{ Cumulative \% Drug Release } \\
\hline & Without Hydrocolloid (F1) & With Hydrocolloid (F2) \\
\hline 0 & 0 & 0 \\
\hline 15 & $25.58 \pm 0.63$ & $18.85 \pm 0.85$ \\
\hline 30 & $38.75 \pm 0.84$ & $27.76 \pm 0.39$ \\
\hline 45 & $51.38 \pm 0.42$ & $36.12 \pm 0.51$ \\
\hline 60 & $64.05 \pm 0.62$ & $47.66 \pm 0.15$ \\
\hline 75 & $72.03 \pm 0.50$ & $55.83 \pm 0.27$ \\
\hline 90 & $81.43 \pm 0.33$ & $63.41 \pm 0.26$ \\
\hline
\end{tabular}

*Each reading is a mean of three replicates.

*Each sample of $1 \mathrm{gm}$. paste contains $250 \mathrm{mcg}$ of drug.

\section{Conclusion}

From our study it was revealed that Beclomethasonedipropionate dental paste formulation should be useful for treatment of periodontitis and oral thrush. The present work revealed that the prepared Beclomethasonedipropionate dental paste formulations with short retentive time also useful in dental disorders. The present work is being focused on designing of medicated tooth pastes to protect the gums, teeth and oral cavity from periodontal infections and oral thrush results from improper fixation of artificial dentures.

\section{Acknowledgement}

The authors are thankful to principal, HKE's M trips, Gulbarga, for providing necessary facilities.

\section{References}

1. Petersen PE (2003) The World Oral Health Report 2003: Continuous improvement of oral health in the $21^{\text {st }}$ century- the approach of the
WHO Global Oral Health Programme. Community Dent Oral Epidemiol 31(Suppl 1): 3-23.

2. Petersen PE, Bourgeois D, Ogawa H, Estupinan-Day S, Ndiaye C (2005) The global burden of oral diseases and risks to oral health. Bull World Health Organ 83(9): 661-669.

3. Petersen PE (2005) The burden of oral disease: challenges to improving oral health in the $21^{\text {st }}$ century. Bull World Health Organ 83(1): 3.

4. Rautemaa R, Lauhio A, Cullinan MP, Seymour GJ (2007) Oral infections and systemic disease- an emerging problem in medicine. ClinMicrobiol Infect 13(11): 1041-1047.

5. Yeo BK, Lim LP, Pquette DW, Williams RC (2005) Periodontal disease: the emergence of a risk for systemic conditions, pre-term low birth weight. Ann Acad Med 34(1): 111.

6. (1987) Cooper and Gunn's, Dispensing for Pharmaceuticals students, (12 ${ }^{\text {th }}$ edn), CBS Publication, New Delhi, India, pp. 210-214.

7. Cruickshank KR (1968) Medical Microbiology, (11 ${ }^{\text {th }}$ edn), Livingstone Ltd, London, USA, p. 268.

8. Patel RP, Kamani R (2009) Formulation optimization and evaluation of mometazonefuroate cream. Journal of pharmacy research October 2(10): 1565-1569.

9. Sethi PD (2001) Qualitative analysis of drug in pharmaceutical formulation. CSBC Publisher's, Netherlands, pp. 220-221.

10. (1993) Indian standard Toothpaste-Specification IS 6356: 1993 (Second Revision). Bureau of Indian Standards: New Delhi, India, pp: $1-6$.

11. (1978) Indian standard, Specification for Hair Creams. ( $1^{\text {st }}$ edn), Indian Standard institution, New Delhi, India, pp. 11-12.

12. Gupta GD, Gaud RS (2005) Release rate of tenoxicam from acrypol gels. The Indian Pharmacist, pp. 69-76.

13. Lakshmanaprabu S, Shirwaikar A (2009) Evaluation of rosin as a cream base for topical ketoconazole preparation. Journal of Pharmaceutical Research 8(2): 89-92.

14. Shrikhande BK, Goupale DC (2001) Development and evaluation of anti-inflammatory oleogels of Bosewelliaserata (gugul) and curcuma longa (turmeric). Indian drugs 38(12): 613-616.

15. Kavitha K, Sivaramakrishnan M (2003) Formulation and evaluation of topical drug delivery systems of fluconazole. Indian drugs $40(12)$ : 720-723.

16. Klimundova J, Sklenarova H (2005) Automated system for release studies of salicylic acid based on a SIA method. J Pharm Biomed Anal 37(5): 893-898. 
(CC) Commons Attribution 4.0 Licens

BY DOI: 10.19080/AIBM.2017.06.555698

\section{Your next submission with Juniper Publishers} will reach you the below assets

- Quality Editorial service

- Swift Peer Review

- Reprints availability

- E-prints Service

- Manuscript Podcast for convenient understanding

- Global attainment for your research

- Manuscript accessibility in different formats

( Pdf, E-pub, Full Text, Audio)

- Unceasing customer service

Track the below URL for one-step submission https://juniperpublishers.com/online-submission.php 